\title{
Health Care Personnel's Attitude toward Hand Hygiene in Regard to the Prevention of Health-Care Associated Infections: A Cross Sectional Study at the University Hospital Pristine
}

\author{
Idriz Sopjani \\ Dean of Nursing Faculty, AAB University, Pristine, Kosovo \\ Email: idriz.sopjani@universitetiaab.com
}

How to cite this paper: Sopjani, I. (2016) Health Care Personnel's Attitude toward Hand Hygiene in Regard to the Prevention of Health-Care Associated Infections: A Cross Sectional Study at the University Hospital Pristine. Open Journal of Nursing, 6, 841-852.

http://dx.doi.org/10.4236/ojn.2016.610083

Received: September 23, 2016

Accepted: October 22, 2016

Published: October 25, 2016

Copyright $\odot 2016$ by author and Scientific Research Publishing Inc. This work is licensed under the Creative Commons Attribution International License (CC BY 4.0).

http://creativecommons.org/licenses/by/4.0/

\section{(c) (i) Open Access}

\begin{abstract}
Background: Hand hygiene is the leading measure for preventing the spread of antimicrobial resistance and reducing healthcare-associated infections, but health care worker compliance with optimal practices remains low in most settings. Objective: The main aim of this paper is to determine findings and start drafting policies in implementing them into practice after finding out nurses' opinions, beliefs and attitudes toward hand hygiene (HH). Methodology and methods: A cross sectional descriptive and observational study during November 2009. Results: From the total number of 175 health care workers employed in this unit, 67 (38.3\%) were observed regarding adherence to hand hygiene. Regarding the knowledge, practices and attitudes of the nurses, data were collected from 54 (50.0\%) among 108 nurses in four intensive care units within the University Clinical Centre of Kosovo (UCCK). From research findings, it was concluded that hand hygiene compliance in the intensive care units was low (51.3\%). Conclusion: Research results show the necessity of organizing multimodal programs with intensive care units of University Clinical Centre of Kosovo (UCCK) on increase of knowledge level on health-care associated infections (HAI).
\end{abstract}

\section{Keywords}

Health-Care Associated Infections, Hand Hygiene, Intensive Care Units

\section{Introduction}

Kosovo is a country with a surface of $10.877 \mathrm{~km}^{2}$ and over 2.5 million population with an average age of 24 and with a gender structure slightly in a favor of males (50.5\%). 
More than half of the population (53\%) is younger than 25 [1]. Kosovo declared its independence in February 2008 and it is one of the poorest countries of Europe. Communicable diseases in Kosovo are still the largest ongoing healthcare problem. The annual per-capita government expenditure on healthcare is only $45 \$[2]$.

University Clinical Centre of Kosovo (UCCK) is the only centre of tertiary care in Kosovo. It has got 2400 beds. Three most frequent groups of diseases recorded in the UCCK during 2005 were as following: respiratory system diseases with $11.84 \%$ of the cases, bloodstream infections with $9.80 \%$ and the third in range were infectious diseases with $8.03 \%$ [3].

Kosovo is part of the International Nosocomial Infection Control Consortium (INICC) through participation in the project: prospective, multi-centre study evaluating costs, risk factors, and rates of Hospital-acquired infections (HAI) in UCUs, which includes 75 hospitals in 24 countries from four continents [4].

\section{Literature Review}

The infection has to be differentiated from colonization that means continuance of the presence of microorganism in the skin, body fluids and bodily tissues however, without clinical repercussions [5]. HAIs are called those infections that a patient caught while hospitalized, while being cured for any other disease [6]. Hospital-acquired infections are called also Nosocomial Infections. In 1843 a Hungarian obstetric established foundations of the discipline of infection control and hospital epidemiology by recommending hand washing method by chlorinated water in order to prevent and reduce incidence of puerperal fevers [7]. While, in 1867 Joseph Lister, by conducting a study on the role of bacteria in infectious of surgical wounds and use of antiseptic sprays in the surgery theatres, established principles of sepsis and antisepsis [8].

Many studies have shown a positive correlation between increase of hand hygiene and reduction of hospital acquired infections [9]. Proper hand hygiene is an efficient method of prevention against spreading microorganism among health staff and the patients [10]. The risk of HAI is 2 to 20 times higher in developing than in developed countries [11]. While reviewing published reports on impact of infection control programs 1990-2002, was found that HAI can be prevented from $10 \%$ to $70 \%$ [12]. Thus, in the Intensive Care Unit in San Paulo Clinic, Brazil, was noticed a decline of $71 \%$ of all HAI following the implementation of HAI Infections Control Program, whereby were saved 2 million dollars [13].

High rate of incidence of bacterial infections in the intensive care unit might be a consequence of improper facility where is located this unit, as well as failure to meet criteria envisaged by SCCM (the society of critical care medicine) for architecture of intensive care unit. According to the criteria, intensive care unit must be a special unit within the hospital with safeguarded access. There shouldn't be allowed any possible access through this unit to the other ones [14]. In Kosovo, all microbiological tests and analysis are performed in the National Institute of Public Health that is located in a remote facility away from intensive care unit. Therefore, the great possibility for con- 
tamination enhancement exists.

If implemented as it is supposed to, hand hygiene can reduce microbial pathogens and cross transmission of infections to community as well as to the health care workers [15]. Thus, it is not only the patients that are subject to hospital acquired infections however; both doctors and nurses are exposed to this risk. A research conducted in Pristine collected opinions of the nurses. Out of the total number of the respondents $78 \%$ of them stated that there exist health risk factors in their work place. $72 \%$ agreed that chemical factors are also a great risk that endangers the health of health care workers and $91 \%$ of them agreed that they were exposed to biological risk factors (bacteria, viruses, etc), while only $19 \%$ always wore gloves when dealing with body secretions [16].

To be successful in increasing compliance, a multimodal strategy should be implemented where should be included at least 5 components: education of staff; monitoring of practices; information on performance; adoption of a regulation of institutional security and finally use of alcohol based hand rub, pursuant to the new patient care [17]. Effectiveness of alcohol based hand rub compared to hands washing with soap is shown by many authors' research [18].

Data of various authors speak differently about the importance of multimodal programs on promotion of hand hygiene by measuring compliance before and after implementation of those programs. Thus "My five moments for hand hygiene" bridges the gap between scientific evidence and daily health practice and provides a solid basis to understand, teach, monitor and report hand hygiene practices [19]. Another study showed that the only motivation factor for hand hygiene compliance was training on hand hygiene [20]. Also Lam, Lee, \& Lau (2004) showed that a problem based and task orientated education program can improve hand hygiene compliance [21]. Furthermore, a number of other studies have shown that educational programs can effectively increase knowledge, positive attitudes and appropriate practice to ensure compliance with international protocols and regulations for the prevention and control of NI [22] [23].

\section{Methodology and Methods}

A cross-sectional descriptive and observational study was used in order to cover all elements of research purposes. This research method was chosen because of its suitability to present information on current situation [24]. A structured questionnaire was designed to conduct this research and elicit written responses about attitudes, beliefs, opinions, compliance, barriers and motivation to comply with hand hygiene guidelines.

\subsection{Credibility and Validity}

The paper aimed implementation of a part of WHO Campaign "Clean Care is safer Care and Save Live" which so far has been implemented in 121 countries of the world, while this was the first time of such an activity to take place in Kosovo. This campaign is composed of the multimodal strategy and is split into five scopes of application as 
follows:

1) Tools for System Change

2) Tools for Training/Education

3) Tools for Evaluation and Feedback

4) Tools for reminders in the workplace

5) Tools for Institutional Safety Climate.

I have chosen the third area "Tools for Evaluation and Feedback", which has in total eight questionnaires, however only five of them were selected as follows:

1) Observation Form and Compliance Calculation Form-to monitor hand hygiene.

2) Ward Infrastructure Survey-to collect data about structures and resources at ward level

3) Soap/Hand rub Consumption Survey - to capture data on usage of hand hygiene resources

4) Perception Survey for Health-care Workers-to assess perceptions of health careassociated infection and hand hygiene

5) Hand Hygiene Knowledge questionnaire for Health-Care Workers-to assess knowledge on the essential aspects of $\mathrm{HH}$.

From these questionnaires was conceived a single questionnaire to synthesize sufficient information about usage of $\mathrm{HH}$ resources and infrastructure; about hand hygiene actions and compliance calculation; about perception and hand hygiene knowledge of health care workers.

\subsection{Sample}

Participants, as a part of the research group had enough time to fill questionnaire starting from 19-27 November 2009. There was a satisfactory response corresponding to the distributed number. 54 nurses (100\%) and 4 (100\%) senior managers in four intensive care units of the University Clinical Centre of Kosovo volunteered to participate in the survey during November 2009. As regards knowledge, attitudes and practices of the nurses, data were collected from a sample of 54 among of 108 nurses in four intensive care units within UCCK. Also, for implementation of hand hygiene it was conducted surveillance of infrastructure of the units and the health care workers. Out of the total number of 175 health care workers employed in the units, 67 (38.3\%) were observed.

Before 2006, education level of nurses in Kosovo was mainly medical high school. But after 2006, education level changed by increasing the number of nurses with higher education (bachelor degree). The four senior managers had finished high school and they had 10 to 20 years working experience on nursing. While among 54 nurses, 30 of them had finished nursing high school and 24 high school of nursing. 15 nurses had 10 20 years working experience, 4 nurses had over 20 years of work and 35 nurses had less than 10 years working experience.

Data collected through questionnaires were analyzed by using statistical program SPSS version 17.0. Some of them were coded from 1 to 7 point rating of Liker scale. Study design is shown in Figure 1. 


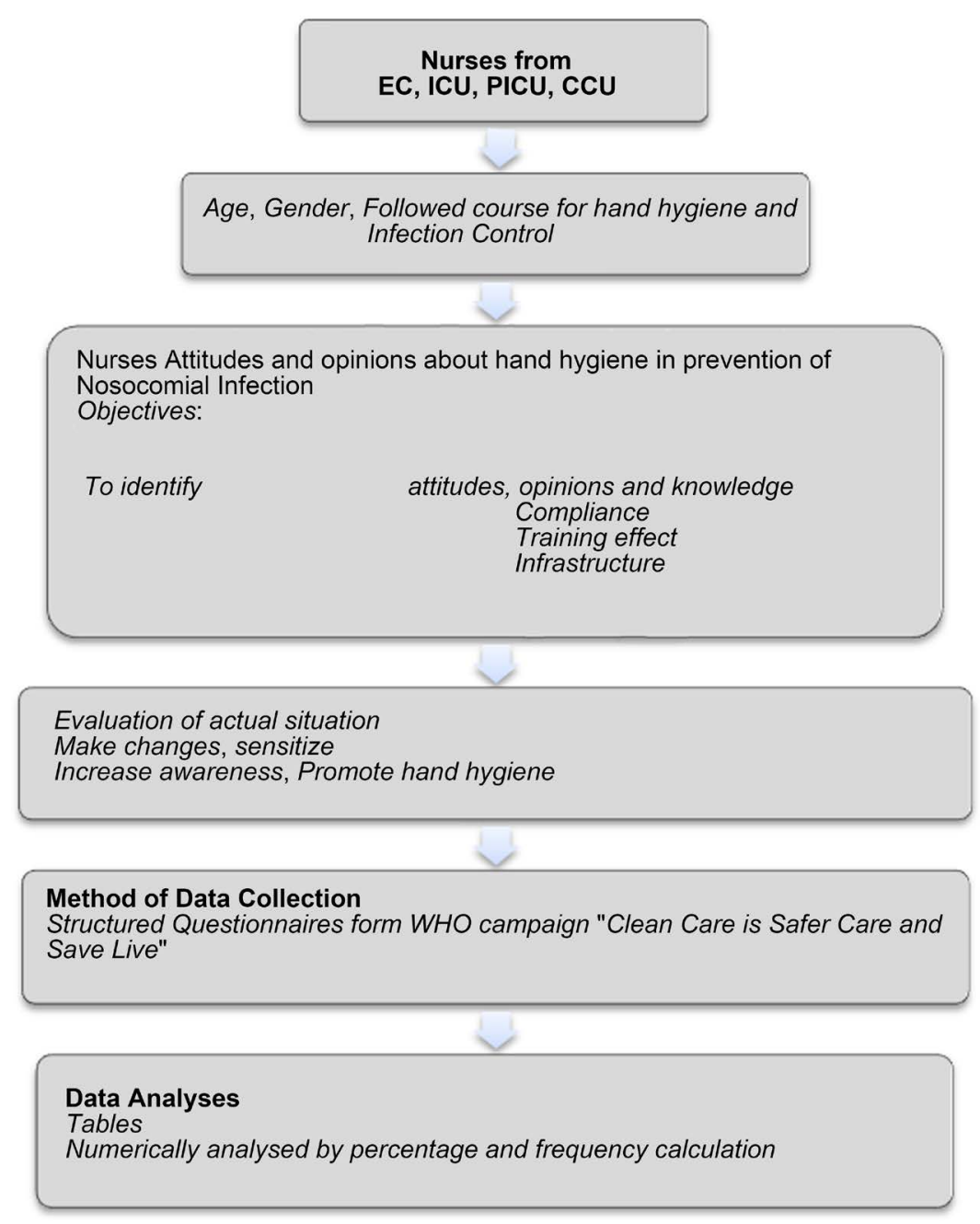

Figure 1. Design of the study.

\subsection{Ethical Issues}

In order to implement those questionnaires, I have asked for permission and addressed to WHO Europe Office in Copenhagen. After obtaining the approval from WHO on $10 / 26 / 2009$, I have proceeded with translation of questionnaires from English into Albanian and vice versa in order to measure validity of the questionnaire and preserve comprehensiveness of the questions. Permission for conducting this research was obtained from nursing director prior starting with collection of data since Kosovo hospitals had no ethical committees until then. Together with UCCK Nursing Director, we assigned units where to implement and conduct observation of the questionnaires.

The participants were guaranteed complete discretion. Each and every participant was informed about the aim of the research through a cover letter. Also, my signature and contact address was included in the cover letter. The questionnaire was anonymous and with instructions how to fill it out. Participants were promised that the questionnaires would be destroyed after the data analysis. 


\section{Results}

Four intensive care units within University Hospital Pristine were included in the observation: main intensive care unit, coronary unit, post intensive unit and emergency center. In the post intensive care observation were four beds; 14 nurses and 4 doctors. During observation there were observed 6 practitioners. In the main intensive care were 14 beds; 40 nurses; 17 doctors and 4 assistants; and there were observed 16 health care workers. Emergency center had 17 beds; 40 nurses; 10 doctors and 25 assistants; and there were observed 41 health care workers. While in the coronary unit were 13 beds, 14 nurses, 5 doctors and there were observed 4 health care workers.

\subsection{Infrastructure and Usage of $\mathrm{HH}$ Resources}

Supply of those four units by hygiene products is carried out by central level on regular basis. Alcohol based hand rub (liquid) was used in all units. In the emergency center and in the main intensive center was used medical soap (average use of $100 \mathrm{~L}$ ); in the post intensive unit and in the coronary unit was used liquid (respectively average use of $10 \mathrm{~L}$ and $13 \mathrm{~L}$ ). There was available tap water in all units on regular basis. According to the senior managers, single use towels and alcohol based hand rub were available time after time, and not all rooms were equipped with them. Next to every washbasin were displayed posters of hand washing technique.

\subsection{Observation Results of Hand Hygiene Actions and Compliance Evaluation}

Out of 175 health care workers, 67 (38.3\%) were observed during their performance. There were observed 312 actions out of which vast majority of 100 (31\%) after body fluid exposure risk, 65 (21\%) before touching a patient, 59 (19\%) after touching a patient, $54(18 \%)$ after touching patient surroundings and $34(11 \%)$ before clean/aseptic procedure.

Compliance of 67 observed nurses for hand hygiene was 51.3\%; the highest compliance was after body fluid exposure risk (93.0\%) and gloves were used most frequently after body fluid exposure risk by 35 (53.0\% of respondents). In other cases, the compliance was much lower than $50.0 \%$. Thus, compliance after touching a patient was 44.1\%; after touching patient surroundings $38.9 \%$; before clean/aseptic procedure $23.5 \%$ and the lowest before touching a patient $18.5 \%$ (Table 1). To evaluate compliance was used the following formula:

Compliance $=$ Hand hygiene actions performed/hand hygiene action required

\subsection{Results Regarding Perception Survey}

In this survey were involved 54 nurses as sample. Out of them 44 (81.5\%) were females and $10(18.5 \%)$ males. Average age of the involved nurses in the survey was 25.3 years old $(\mathrm{SD} \pm 5.4 \mathrm{yr})$, median 25 years. The youngest nurse was 19 years old and the oldest one was 47 years old. Intensive care unit sample of nurses was 10 (18.5\%), coronary unit $9(16.7 \%)$, post intensive unit $4(7.4 \%)$, emergency center $10(18.5 \%)$ and nurse 
students 21 (38.9\%). 19 (35.2\%) nurses had taken formal training on hand hygiene. 39 (72.2\% of respondents) answered positively when they were asked if they used routinely an alcohol based hand rub for hand hygiene.

Out of all the actions on improving hand hygiene mentioned in Table 2, 35 (64.8\%) nurses agreed with hand hygiene performing as recommended (being a good example for your colleagues) as the most effective action to improve hand hygiene in institution. This is shown by the highest average of a point rating scale 5.6. Then as the second most effective action for 29 (53.7\% of respondents) was "Hand hygiene posters are displayed at point of care as reminders", followed by other actions as shown in Table 2.

Table 1. Compliance evaluation.

\begin{tabular}{cc}
\hline & Compliance \\
\hline Before touching a patient & $18.5 \%$ \\
Before clean/aseptic procedure & $23.5 \%$ \\
After body fluid exposure risk & $93.0 \%$ \\
After touching a patient & $44.1 \%$ \\
After touching patient surroundings & $38.9 \%$ \\
Total & $51.3 \%$ \\
\hline
\end{tabular}

Table 2. Effective actions to improve HH.

\begin{tabular}{|c|c|c|c|c|c|c|c|c|c|}
\hline \multicolumn{2}{|l|}{$\begin{array}{c}\text { How effective would the following actions be } \\
\text { to improve HH permanently in your } \\
\text { institution? }\end{array}$} & 苍密 & 2 & 3 & 4 & 5 & 6 & 完 & mean \\
\hline \multirow{2}{*}{$\begin{array}{l}\text { Leaders and SM at your institution } \\
\text { support and openly promote } \mathrm{HH}\end{array}$} & $\mathrm{N}$ & 6 & 6 & 8 & 10 & 3 & 5 & 16 & \multirow{2}{*}{4.4} \\
\hline & $\%$ & 11.1 & 11.1 & 14.8 & 18.5 & 5.6 & 9.3 & 29.6 & \\
\hline \multirow{2}{*}{$\begin{array}{l}\text { The HCF makes AHR always available at } \\
\text { each point of care }\end{array}$} & $\mathrm{N}$ & 5 & 4 & 7 & 15 & 6 & 2 & 15 & \multirow{2}{*}{4.5} \\
\hline & $\%$ & 9.3 & 7.4 & 13 & 27.8 & 11.1 & 3.7 & 27.8 & \\
\hline \multirow{2}{*}{$\begin{array}{l}\text { HH posters are displayed at point of care } \\
\text { as reminders }\end{array}$} & $\mathrm{N}$ & 1 & 5 & 7 & 5 & 5 & 2 & 29 & \multirow{2}{*}{5.4} \\
\hline & $\%$ & 1.9 & 9.3 & 13 & 9.3 & 9.3 & 3.7 & 53.7 & \\
\hline \multirow[b]{2}{*}{ Each $\mathrm{HCW}$ receives education on $\mathrm{HH}$} & $\mathrm{N}$ & 6 & 3 & 10 & 10 & 5 & 5 & 15 & \multirow[b]{2}{*}{4.5} \\
\hline & $\%$ & 11.1 & 5.6 & 18.5 & 18.5 & 9.3 & 9.3 & 27.8 & \\
\hline \multirow{2}{*}{$\begin{array}{l}\text { Clear and simple instructions for } \mathrm{HH} \\
\text { are made visible for every } \mathrm{HCW}\end{array}$} & $\mathrm{N}$ & 3 & 3 & 9 & 5 & 4 & 5 & 25 & \multirow{2}{*}{5.2} \\
\hline & $\%$ & 5.6 & 5.6 & 16.7 & 9.3 & 7.4 & 9.3 & 46.3 & \\
\hline \multirow{2}{*}{$\begin{array}{l}\text { HCW regularly receive feedback on their } \\
\text { HH performance }\end{array}$} & $\mathrm{N}$ & 6 & 1 & 15 & 9 & 2 & 4 & 17 & \multirow{2}{*}{4.5} \\
\hline & $\%$ & 11.1 & 1.9 & 27.8 & 16.7 & 3.7 & 7.4 & 31.5 & \\
\hline \multirow{2}{*}{$\begin{array}{l}\text { You always perform } \mathrm{HH} \text { as } \\
\text { recommended (being a good example } \\
\text { for your colleagues) }\end{array}$} & $\mathrm{N}$ & 3 & & 9 & 5 & 2 & & 35 & \multirow[b]{2}{*}{5.6} \\
\hline & $\%$ & 5.6 & & 16.7 & 9.3 & 3.7 & & 64.8 & \\
\hline \multirow{2}{*}{$\begin{array}{l}\text { Patients are invited to remind } \mathrm{HCW} \text { to } \\
\text { perform } \mathrm{HH}\end{array}$} & $\mathrm{N}$ & 15 & 4 & 11 & 9 & 1 & 1 & 13 & \multirow{2}{*}{3.6} \\
\hline & $\%$ & 27.8 & 7.4 & 20.4 & 16.7 & 1.9 & 1.9 & 24.1 & \\
\hline
\end{tabular}


Vast majority of nurses, $30(57.4 \%)$ answered that their hands tolerate very well alcohol based hand rubs. 27 (50\% of respondents) perceived hand hygiene observation in their ward as a helpful tool to improve hand hygiene for themselves and their colleagues. Regarding the question "Has the fact of being observed made you paying more attention to your hand hygiene?" 26 nurses or $48.1 \%$ of respondents answered very much.

\subsection{Results Regarding Hand Hygiene Knowledge}

$45(83.3 \%)$ participants were aware that health care workers hands when not clean are the main route of cross-transmission of potentially harmful germs between patients in a health care facility. The others answered: on air circulating in the hospital only $3(5.6 \%)$, on patients' exposure to colonized surfaces only $2(3.7 \%)$, on sharing non-invasive objects $4(7.4 \%)$.

Vast majority of respondents 31 (57.4\%) chose hospital environment as the most frequent source of germs responsible for health care associated infections, followed by other answers as "germs already present on or within the patient" from $12(22.2 \%)$, hospital's water system from 8 (14.8\%) and hospital air only 3 (5.6\%).

Regarding the hand hygiene actions that prevent transmission of germs to patient, 46 (85.2\% of respondents) answered correctly "before touching a patient", 7 (13\%) answered correctly "No, immediately after a risk of body fluid exposure", $44(81.5 \%)$ answered correctly "after exposure to the immediate surroundings of a patient" and 8 (14.8\%) answered correctly "No, immediately before a clean/aseptic procedure". This means that a considerable number of nurses not knew the right answer.

Level of knowledge on use of alcohol hand rubbing and hand washing was rather low. On statement "hand rubbing is more rapid for hand cleansing than hand washing" $21(38.9 \%)$ answered correctly (True statement); on statement " hand rubbing causes skin dryness more than hand washing”, 17 (31.5\%) answered correctly (False statement); on statement " hand rubbing is more effective against germs than hand washing", 12 (22.2\%) answered correctly (True statement) and on the last statement "hand washing and hand rubbing are recommended to be performed in sequence" only 5 (9.3\%) answered correctly (False statement).

Regarding the minimal time needed for alcohol hand rubbing to kill most germs on hands, 12 (22.2\%) answered correctly (20 seconds).

Level of knowledge on hand hygiene methods that should be used in different situations is not satisfactory. Only 18 (33.3\%) gave the right answer regarding before palpation of the abdomen (rubbing), before giving an injection only 6 (11.1\%) gave the right answer rubbing, after emptying a bedpan (rubbing) only 3 (5.6\%) answered correctly, after removing examination gloves (rubbing) only 8 (14.8\%) answered correctly, after making a patient's bed" (rubbing) only $3(5.6 \%)$ answered correctly and the last one regarding "after visible exposure to blood" 33 (61.1\%) answered correctly (washing).

\section{Discussion}

Another topic on the attitudes of health care workers related to hand hygiene in 
prevention of intra hospital infections has not been surveyed earlier in the University Clinical Center of Kosovo. Those circumstances make impossible comparison of the research findings to the institutional preliminary data. Results of the research show that in the intensive care units within University Hospital in Pristine exists a very weak infrastructure with a very poor supply of hand hygiene maintenance products, low level of knowledge on HAI, routes and transmission possibilities of those infections associated with low scale of hand hygiene compliance.

Furthermore, it's been registered a low level of knowledge on hand washing techniques. Nurses involved in the study think that the managers have an important role to play as regards increase of hand hygiene compliance, observation and educational programs. Also, research results show the necessity of organizing multimodal programs with intensive care units of UCCK on increase of knowledge level on HAI and importance of hand hygiene for prevention of those infections. Data analysis yielded valuable information about the key elements like attitudes, beliefs, opinions and knowledge of the phenomenon studied. Those accomplishment are very important, because so far in Kosovo, has never been implemented the strategy "Clean hands are safer hands".

From research findings it is concluded that hand hygiene compliance in the intensive care unit was low (51.3\%). Findings revealed that the highest compliance was $93.0 \%$ after body fluid exposure risk. In other cases the compliance was lesser than $50.0 \%$. However, there is poor compliance with hand hygiene regulations by healthcare workers all over the world, and all studies conducted in hospitals suggest that the frequency of compliance is lower than $50.0 \%$ of the opportunities in which the practice is considered a priority [25]. Thus, Saint, et al. (2009) reported low compliance of hand hygiene $(56.0 \%)$ in one region in Italy (Tuscany) similarly to my data [26]. The data highlighted that nurses were conscientious in their approach to infection prevention and control. Referring to the results, majority of the respondents 45 (83.3\%) considered hand hygiene as necessary measure to prevent infection. Very small number is aware about the most frequent source of infection 12 (22.2\%). Only 8 (14.8\%) knew that they had to perform hand washing immediately before a clean/aseptic procedure. There are different factors contributing to low levels of hand hygiene compliance such as: lack of knowledge of the importance of preventing HAIs, heavy workload, lack of understanding the appropriate techniques involved, etc.

Research conducted in the University Hospitals are individual researches for studying purposes and are not organized by the management, therefore in most cases there is no feedback. Most of the respondents 45 (83.3\%) were aware that health care workers hands when not clean are the main route of cross-transmission of potentially harmful germs between patients in a Health Care Facility. The right answer, the germs already on or within the patient was given only by 12 (22.2\%). According to Boyce, (2001) hand cleansing with alcohol solutions can cause irritant and dry skin based on the products where alcohol based products did not contain emollients since products containing emollients cause less damage to the skin [27]. Thus, based on these findings, 30 (57.4\%) nurses involved in the study answered that their hands tolerate quite well alcohol based 
solutions. That means that UCCK health care workers either do not perform regular alcohol based hand rub or they use alcohol solution containing emollients.

Gloves were used most frequently 35 (53.0\%) after body fluid exposure risk, while in a study of Nobile, Montuori, Diaco, \& Villari (2002) 165 (60\%) wore gloves while providing health care [28].

\section{Conclusions}

The results of this study show that we should get started with policy drafting and their implementation into practice with a scope to sensitize health care workers aiming enhancement of hand hygiene compliance in the hospital. Health care workers' hands are the most common transmission source of healthcare-associated pathogens from patient to patient and within the healthcare environment.

Moreover, research findings show that there is a shortage of regular supply with hygiene adherence means and the architectonics of intensive care units does not meet conditions according to the standards. As well would be beneficial organizing short-term trainings on hand hygiene and infection control with participation of nonmedical staff (cleaners and kitchen service).

Besides novelties that brought this paper to local literature, the study had several limitations. One of the limitations was the sample size, which was very small (54 nurses). In order for the findings to be representative of the entire population of health care workers, it is necessary to take into account a greater sample and representative. Another limitation was the time period in which observation was conducted. It would be preferable to extend the time period in order to get fruitful results.

Referred to the research data of this study one recommendation to increase hand hygiene among nurses in the hospital is drafting policies and guidelines in order to regulate the necessity of hand hygiene in medical settings. Education of nurses on promoting hand hygiene washing should be conducted consecutively each year. Health care workers should be supplied all the time with hygienic stuff in all places in the hospital. These supplies should include liquid soap, paper towels for hand drying, etc. Infection control committee should monitor nurses during their daily work. Research results showed that full implementation of WHO campaign "Clean Care is Safer Care and Save lives" is the indispensable for Kosovo. To date the campaign has been implemented over 121 countries of the world.

\section{References}

[1] SOK (2005) Vital Statistics in Kosovo for Year 2004. Statistical Office of Kosovo, Pristine.

[2] Raka, L., Zoutman, D., Mulliqi, G., Krasniqi, S., Dedushaj, I., Raka, N., et al. (2006) Prevalence of Nosocomial Infections in the High Risk Units at the University Clinical Center of Kosova. Infection Control, 27, 421-423. http://dx.doi.org/10.1086/503387

[3] NIPHC (2006) Morbidity Registred on Health Institutions in Kosova on 2005. National Institute of Public Health of Kosova, Prishtinë.

[4] Raka, L., Mulliqi, G., Dedushaj, I., Krasniqi, S., Gjergji, T., Krasniqi, A., et al. (2009) Denial, Media and Endurance in Infection Control in Kosova. International Journal of Infection 
Control, 5, 1-5. http://dx.doi.org/10.3396/ijic.V5i1.007.09

[5] Marino, P.L. and Sutin, K.M. (1998) The ICU Book (Vol. 2). Williams \& Wilkins, Baltimore.

[6] Cika, V. (2001) Infeksionet brendaspitaleve dhe masat parandaluese. DRIER, Tiranë, 283329.

[7] Skopec, M. and Wykticky, H. (1983) Ignaz Philipp Semmelweis, the Prophet of Bacteriology. Infection Control, 4, 367-370. http://dx.doi.org/10.1017/S0195941700059762

[8] Alexander, J.W. (1985) The Contributions of Infection Control to a Century of Surgical Progress. Annals of Surgery, 201, 423-428. http://dx.doi.org/10.1097/00000658-198504000-00004

[9] Mediå, A.K. (2008) A Comparative Analysis of Two Cross-Sectional Surveys of Healthcare Workers' Hand Hygiene Knowledge, Intentions, Access and Product Preferences between Two University Hospitals, One in Norway and One in Canada. http://hdl.handle.net/10037/1805

[10] French, G., Lynch, P., Hambraeus, A., Mehtar, S., Heeg, P., Saint, S. and Kolmos, H.J. (2003) Infection Control: Basic Concepts and Training. 2.udgave Edition, International Federation of Infection Control (IFIC), USA.

http://findresearcher.sdu.dk/portal/en/publications/infection-control-basic-concepts-andtr aining(24cacc80-6fd1-11db-81a9-000ea68e967b).html

[11] Pittet, D. (2005) Clean Hands Reduce the Burden of Disease. The Lancet, 366, 185-187. http://dx.doi.org/10.1016/S0140-6736(05)66886-9

[12] Harbarth, S., Sax, H. and Gastmeier, P. (2003) The Preventable Proportion of Nosocomial Infections: An Overview of Published Reports. Journal of Hospital Infection, 54, 258-266. http://dx.doi.org/10.1016/S0195-6701(03)00150-6

[13] Cavalcante, M.D., Braga, O.B., Teofilo, C.H., Oliveira, E.N. and Alves, A. (1991) Cost Improvements through the Establishment of Prudent Infection Control Practices in a Brazilian General Hospital, 1986-1989. Infection Control \& Hospital Epidemiology, 12, 649-653. http://dx.doi.org/10.2307/30146897

[14] O’Connell, N.H. and Humphreys, H. (2000) Intensive Care Unit Design and Environmental Factors in the Acquisition of Infection. Journal of Hospital Infection, 45, 255-262. http://dx.doi.org/10.1053/jhin.2000.0768

[15] Pittet, D., Hugonnet, S., Harbarth, S., Mourouga, P., Sauvan, V., Touveneau, S., et al. (2000) Effectiveness of a Hospital-Wide Programme to Improve Compliance with Hand Hygiene. The Lancet, 356, 1307-1312. http://dx.doi.org/10.1016/S0140-6736(00)02814-2

[16] Kryeziu, B. (2009) Opinionet e infermierëve për rrezikuesit shëndetësore në vendet e tyre të punës. Prishtinë.

[17] WHO (2006) WHO Guidelines on Hand Hygiene in Health Care (Advanced Draft): Global Safety Challenge 2005-2006: Clean Care Is Safer Care. World Health Organization, Geneva.

[18] Elola-Vicente, P., Aroca-Palencia, J., Huertas-Paredero, M.V., Díez-Sebastián, J., Rivas-Bellido, L., Martínez-Martínez, G., et al. (2007) A Hand Hygiene Education Program. Comparison between Handwashing and the Use of Alcohol Solutions. Enfermeria Clinica, 18, 5-10. http://dx.doi.org/10.1016/S1130-8621(08)70687-9

[19] Sax, H., Allegranzi, B., Uckay, I., Larson, E., Boyce, J. and Pittet, D. (2007) "My Five Moments for Hand Hygiene": A User-Centred Design Approach to Understand, Train, Monitor and Report Hand Hygiene. Journal of Hospital Infection, 67, 9-21. http://dx.doi.org/10.1016/j.jhin.2007.06.004

[20] Zimakoff, J., Kjelsberg, A.B., Larsen, S.O. and Holstein, B. (1992) A Multicenter Questionnaire Investigation of Attitudes toward Hand Hygiene, Assessed by the Staff in Fifteen 
Hospitals in Denmark and Norway. American Journal of Infection Control, 20, 58-64. http://dx.doi.org/10.1016/S0196-6553(05)80002-1

[21] Lam, B.C., Lee, J. and Lau, Y.L. (2004) Hand Hygiene Practices in a Neonatal Intensive Care Unit: A Multimodal Intervention and Impact on Nosocomial Infection. Pediatrics, 114, e565-e571. http://dx.doi.org/10.1542/peds.2004-1107

[22] Gould, D. and Chamberlain, A. (1997) The Use of a Ward-Based Educational Teaching Package to Enhance Nurses' Compliance with Infection Control Procedures. Journal of Clinical Nursing, 6, 55-67. http://dx.doi.org/10.1111/j.1365-2702.1997.tb00284.x

[23] Huang, J., Jiang, D., Wang, X., Liu, Y., Fennie, K., Burgess, J., et al. (2002) Changing Knowledge, Behavior, and Practice Related to Universal Precautions among Hospital Nurses in China. The Journal of Continuing Education in Nursing, 33, 217-224.

[24] Olsen, C. and St George, D.M. (2004) Cross-Sectional Study Design and Data Analysis. College Entrance Examination Board, New York. http://cdn.physioblasts.org/f/public/1355667773 1 FT0 4297 module 05.pdf

[25] O’Grady, N.P., Alexander, M., Dellinger, E.P., Gerberding, J.L., Heard, S.O., Maki, D.G., et al. (2002) Guidelines for the Prevention of Intravascular. Centers for Disease Control and Prevention, Atlanta.

[26] Saint, S., Bartoloni, A., Virgili, G., Mannelli, F., Fumagalli, S., di Martino, P., et al. (2009) Marked Variability in Adherence to Hand Hygiene: A 5-Unit Observational Study in Tuscany. American Journal of Infection Control, 37, 306-310. http://dx.doi.org/10.1016/j.ajic.2008.08.004

[27] Boyce, J.M. (2001) Antiseptic Technology: Access, Affordability, and Acceptance. Emerging Infectious Diseases, 7, 231. http://dx.doi.org/10.3201/eid0702.010216

[28] Nobile, C.G., Montuori, P., Diaco, E. and Villari, P. (2002) Healthcare Personnel and Hand Decontamination in Intensive Care Units: Knowledge, Attitudes, and Behaviour in Italy. Journal of Hospital Infection, 51, 226-232. http://dx.doi.org/10.1053/jhin.2002.1248

\section{Submit or recommend next manuscript to SCIRP and we will provide best service for you:}

Accepting pre-submission inquiries through Email, Facebook, LinkedIn, Twitter, etc.

A wide selection of journals (inclusive of 9 subjects, more than 200 journals)

Providing 24-hour high-quality service

User-friendly online submission system

Fair and swift peer-review system

Efficient typesetting and proofreading procedure

Display of the result of downloads and visits, as well as the number of cited articles

Maximum dissemination of your research work

Submit your manuscript at: http://papersubmission.scirp.org/

Or contact ojn@scirp.org 